\title{
Analisis Pendekatan Sosioekonomi Pengentasan Pengangguran di Daerah Religi
}

\author{
Agus Lukman Hakim ${ }^{1} *$, Dirlanudin ${ }^{2}$, Agus Sjafari $^{3}$, Atik Atiatun Nafisah ${ }^{4}$, Ade Hadiono ${ }^{5}$ \\ 1,4, Sekolah Tinggi Ilmu Administrasi Banten, Banten, Indonesia \\ ${ }^{2,3}$ Universitas Sultan Ageng Tirtayasa, Banten, Indonesia \\ ${ }^{1}$ aguslukman.hakim@stiabanten.ac.id* \\ * corresponding author
}

\section{ARTICLE INFO}

\section{Article historv}

Received 2019-10-30

Revised -

Accepted 2019-12-18

\section{Keywords}

Unemployment,

Religious regions,

Socioeconomics

\section{ABSTRACT}

Pandeglang Regency community is an agricultural and religious area located in Banten Province which is adjacent to the Capital City of Jakarta. One serious problem that occurs is unemployment in rural areas. This study aims to analyze the problem of unemployment reality with a socioeconomic approach with a handling approach. This research is a descriptive research. Data collection techniques through questionnaires and interviews, through one stage cluster random sampling method. Secondary data used from related institutions / agencies in the Regional Government of Pandeglang Regency. The analysis technique used is descriptive analysis. The results showed the factors causing unemployment in Pandeglang Regency were due to limited employment, limited business capital; unable to compete in business; low awareness of the community in helping to find (invite) work; low work ethic; inability to capture work / business opportunities; low labor costs; work termination; Closed attitude towards life. The dominant contributing factor to unemployment is the first because of limited employment. Second, it is due to limited business capital and third is due to a low work ethic (lazy character).

\section{PENDAHULUAN}

Persoalan pengangguran adalah salah satu isu krusial dalam pembangunan ekonomi makro suatu daerah. Pengangguran merupakan kondisi ketidakmampuan pemerintah dalam memberikan peluang pekerjaan bagi masyarakat yang memasuki angkatan kerja. Isu ini menjadi sentral karena banyaknya pengangguran menimbulkan dampak negatif menurut pendekatan sosioekonomi (Swaramarinda 2014).

Berdasarkan data dari Badan Pusat Statistik (BPS) Provinsi Banten Tahun 2017, tingkat pengangguran di Provinsi Banten tertinggi dibanding angka pengangguran nasional. Pada Agustus 2017, angka pengangguran Provinsi Banten menempati peringkat kedua tertinggi nasional setelah Provinsi Maluku. Tingkat Pengangguran Terbuka (TPT) di Provinsi Banten tahun 2017, dari Kabupaten Serang 13\% dan Cilegon sebesar $11,8 \%$ atau daerah industri perkotaan, Sedangkan penyumbang angka TPT terendah adalah Kota Tangerang Selatan sebesar 6,83\%.

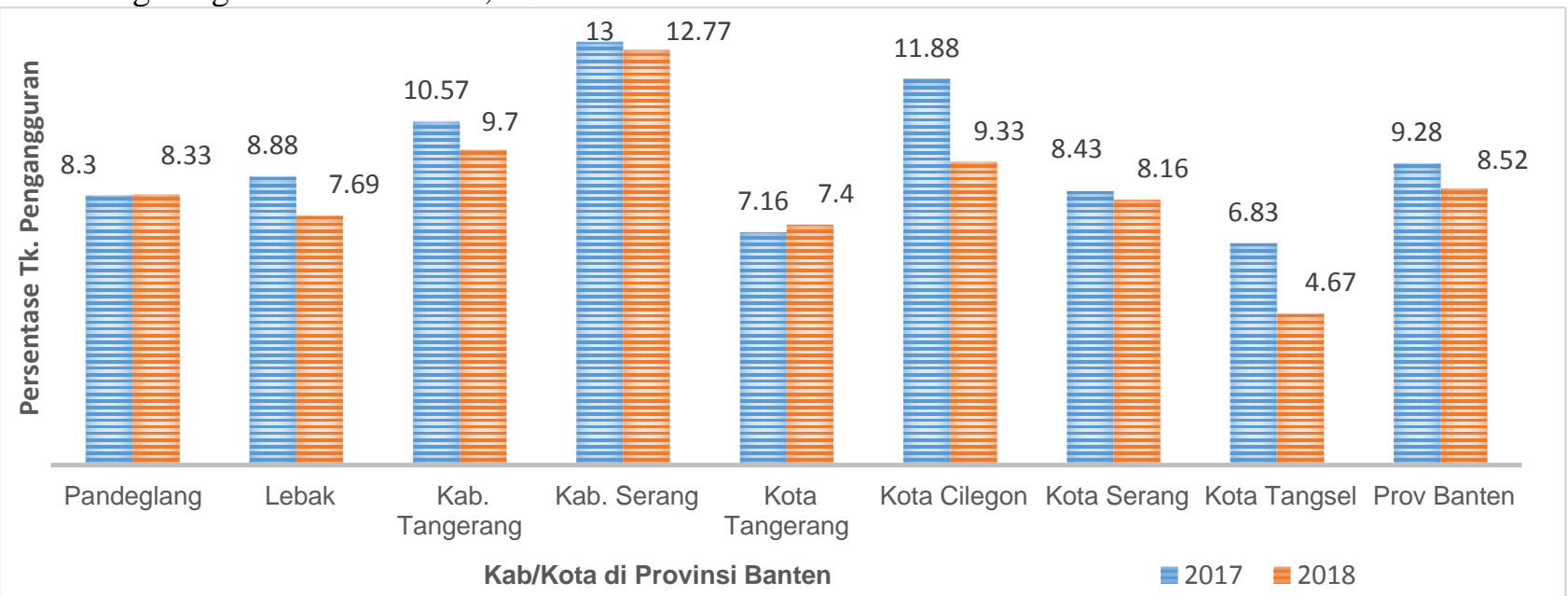

Sumber: BPS Provinsi Banten, 2019

Gambar 1. Tingkat pengangguran di Provinsi Banten 
Adapun tingkat pengangguran terbuka di Kabupaten Pandeglang pada Tahun 2017 sebesar 8,30\%, hal ini sama dengan tahun sebelumnya. Dengan stagnannya angka tersebut tentunya diperlukan perhatian yang serius dari Pemerintah Kabupaten Pandeglang untuk mengurangi jumlah tersebut. Oleh karena itu, dibutuhkan suatu kajian yang lebih mendalam untuk menggali faktor-faktor penyebab pengangguran di wilayah Kabupaten Pandeglang dan upaya-upaya yang tepat yang dapat dilakukan pemerintah daerah dalam menurunkan tingkat pengangguran di daerah ini. Dari fenomena tersebut, pokok permasalahan yang muncul adalah Faktor apakah yang menjadi penyebab utama pengangguran di Kabupaten Pandeglang. Strategi yang mesti dijalankan pemerintah daerah untuk mengurangi jumlah pengangguran di Kabupaten Pandeglang?

\section{LANDASAN TEORI}

Dalam penelitian ini peneliti menggunakan beberapa penelitian dan kajian yang yang relevan, di antaranya:

\section{Faktor Penyebab Pengangguran dalam Perspektif ekonomi}

Budiani (2012) dan Albertus Aditya (2016) menjelaskan pengangguran disebabkan adanya ketidaksesuaian antara permintaan tenaga kerja dan penawaran tenaga kerja. Pengangguran akan muncul dalam suatu perekonomian menurut Kaufman dan Hotckiss (1999) disebabkan oleh tiga hal:

1. Proses mencari kerja. Adanya angkatan kerja baru akan menimbulkan persaingan yang ketat dalam proses mencari kerja sehingga adanya para pekerja yang ingin pindah ke pekerjaan lain. Faktor lain adalah tidak sempurnanya informasi yang diterima pencari kerja mengenai lapangan kerja yang tersedia, serta informasi yang tidak sempurna pada besarnya tingkat upah yang layak mereka terima, dan sebagainya.

2. Kekakuan upah. Besarnya pengangguran yang terjadi dipengaruhi akibat tingkat upah yang tidak fleksibel dalam pasar tenaga kerja. Penurunan pada proses produksi dalam perekonomian akan mengakibatkan penurunan pada permintaan tenaga dan berdampak pada penurunan besarnya upah.

3. Efisiensi upah. Besarnya pengangguran dipengaruhi oleh efisiensi pengupahan. Efisiensi pada fungsi tingkat upah tersebut terjadi karena semakin tinggi perusahaan membayar upah maka akan semakin keras usaha para pekerja untuk bekerja.

\section{Faktor penyebab pengangguran dalam perspektif sosiologis, psikologis dan budaya}

Kajian penelitian ini melihat persoalan pengangguran bukan hanya persoalan ekonomi tetapi juga perlu dianalisis dalam perspektif sosiologis, psikologi dan manajemen SDM karena beberapa studi menunjukkan adanya pengaruh sosioekonomi yang signifikan akan mendorong terjadinya pengangguran. Irpan Fito (2015) menjelaskan faktor-faktor pemyebab pengangguran berupa: 1. Pendidikan rendah 2. Kurangnya lapangan pekerjaan. 3. Rasa malas dan ketergantungan diri pada orang lain. 4. Tidak mau berwirausaha. Menurut Sudrajat (2006 : 6-8) menyebutkan beberapa faktor penyebab terjadinya pengangguran, yakni : 1 . Warisan sifat feodalisme, 2. Tidak ada motivasi untuk bekerja, 3. Lapangan kerja yang tersedia memerlukan keterampilan khusus, 4. Pertumbuhan ekonomi, 5. Menemui jalan buntu dalam mencari pekerjaan.

Beberapa pakar mengklasifikasikan penyebab utama pengangguran baik dalam pendekatan ekonomi, sosiologi maupun psikologi sebagai berikut. Pertama, faktor lapangang pekerjaan. Hal tersebut disebabkan rendahnya Informasi pekerjaan Ketidaksesuaian skill dan pendidikan sebagaimana diperkuat oleh pendapat (Kaufman dan Hotckiss, 1999). Kedua, Modal Usaha. Hal tersebut karena problema Akses permodalan serta Kebijakan pemerintah tentang permodalan (Kaufman dan Hotckiss, 1999). Ketiga, persaingan ekonomi dan solidaritas sosial (Kusuma). Keempat, etos kerja. Etos kerja sangat dipengaruhi oleh need for achievement (Kebutuhan prestasi). Kelima, keratifitas dan inovasi. Aspek yang mempengaruhinya adalah Kreatifitas dalam wirausaha dan survivel of the fittest. Keenam adalah upah kerja. Faktor yang mempengaruhinya adalah Penurunan Upah dan Efisiensi Tenaga kerja. Ketujuh adalah Lagart (Kultur tertutup). Hal tersebut dipengaruhi oleh karakter individu dan masyarakat yang menolak inovasi, tertutup pada informasi, dan Sistem nilai keluarga yang tertutup.

\section{METODE PENELITIAN}

Penelitian ini menggunakan pendekatan kuantitatif. Adapun lokasi penelitiannya di Kabupaten Pandeglang. Populasi adalah Seluruh penganggur yang terdapat di Kabupaten Pandeglang berdasarkan data Dinsosnakertrans Kabupaten Pandeglang (2017). Selanjutnya dari data ini subpopulasi masyarakat 
penganggur diambil dari lima kecamatan yang memiliki tingkat penganggur terbanyak yang masing-masing berasal dari lima zona yang berbeda (N2). Pada tabel 1 dijabarkan sebaran jumlah subpopulasi penganggur beserta ukuran sampelnya

Tabel 1 Sebaran Jumlah Subpopulasi Penganggur Berdasarkan Zona Wilayah

\begin{tabular}{|c|l|c|c|}
\hline ZONA & KECAMATAN & $\begin{array}{c}\text { JUMLAH } \\
\text { PENGANGGUR }\end{array}$ & $\begin{array}{c}\text { JUMLAH } \\
\text { RESPONDEN }\end{array}$ \\
\hline 1 & CIKEUSIK & 231 & 46 \\
\hline 2 & LABUAN & 515 & 103 \\
\hline 3 & SAKETI & 434 & 87 \\
\hline 4 & SINDANGRESMI & 109 & 22 \\
\hline 5 & PANDEGLANG & 642 & 128 \\
\hline & JUMLAH & $\mathbf{1 9 3 1}$ & $\mathbf{3 8 5}$ \\
\hline
\end{tabular}

Selanjutnya untuk menentukan ukuran sampel, menggunakan rumus Slovin dengan dengan menetapkan derajat akurasi pengambilan sampel (d) sebesar $5 \%$ atau tingkat kepercayaan 95\%, sebagai berikut : $\quad n=\frac{N}{\left(1+N e^{2}\right)}$

Sedangkan teknik sampling yang digunakan dalam penelitian ini adalah cluster sampling yaitu teknik memilih sebuah sampel dari kelompok-kelompok unit yang kecil. Sedangkan Metode sampling yang dipilih adalah One-Stage Cluster Sampling, yaitu membagi populasi menjadi kelompok atau kluster. Beberapa kluster kemudian dipilih secara acak sesuai proporsi dari populasi, kemudian seluruh elemen dalam cluster terpilih dijadikan sebagai sampel penelitian.

Adapuan teknik Analisis secara kuantitatif dengan menganalisis pendekatan sosioekonomi yang mempengaruhi pengangguran dan strategi mengatasi pengangguran di Kabupaten Pandeglang. Peneliti melakukan kegiatan analisis data dengan:

\section{a. Uji Validitas}

Pengujian validitas tiap butir digunakan analisis item yaitu mengkorelasikan skor tiap butir dengan skor total yang merupakan jumlah tiap skor butir dengan rumus korelasi Pearson Product Moment:

$$
r_{y x}=\frac{\sum x y}{\sqrt{\left(\sum x^{2}\right)\left(\sum y^{2}\right)}}
$$

Pengolahan uji validitas menggunakan program SPSS versi 17. Syarat minimum untuk dianggap valid bila $\mathrm{r}=0,3$. Jadi bila koefisien korelasi antar skor butir dengan skor total kurang dari 0,3, maka butir instrumen tersebut dinyatakan tidak valid.

\section{b. Uji Reliabilitas}

Sebuah instrumen pengukur data disebut reliabel atau terpercaya menurut Ferdinand (2006) apabila instrumen itu secara konsisten memunculkan hasil yang sama setiap kali dilakukan pengukuran. Mencari reliabilitas instrumen yang skornya bukan $0-1$, tetapi merupakan rentangan antara beberapa nilai, misalnya 0-10 atau 0-100 atau bentuk skala 1-3, 1-5, atau 1-7 dan seterusnya dapat menggunakan rumus Cronbach's Alpha (Umar, 2003). Dalam penelitian ini pengujian reliabilitas instrumen dilakukan dengan "Internal Consistency" untuk mengetahui kehandalan dan konsistensi suatu alat ukur yang dihitung dengan Cronbach's Alpha menggunakan program SPSS.

\section{c. Uji Normalitas Data}

Didasarkan pada pendapat Solimun (2002) bahwa dengan sampel yang besar (100), asumsinya tidak terlalu kritis, landasannya adalah Dalil Limit Pusat (Central Limit Theorm), yaitu bilamana n (sample size) besar, maka statistik dari sampel tersebut akan mendekati distribusi normal, walaupun populasi dari mana sampel tersebut diambil tidak berdistribusi normal. Beranjak dari dalil tersebut maka data dalam penelitian ini pada hakekatnya sudah diasumsikan berdistribusi normal, karena sampel yang diambil 
jumlahnya cukup besar. Namun demikian untuk memastikan bahwa data yang akan dianalisis adalah berdistribusi normal, maka dalam penelitian ini tetap dilakukan uji normalitas dengan menggunakan Kolmogorov Smirnov. Menurut Tim Penelitian dan Pengembangan Wahana Komputer (2005), yaitu bila nilai Sig > 0,05 maka dinyatakan data berdistribusi normal.

\section{d. Analisis Deskriptif}

Analisis deskriptif merupakan analisis data dengan cara mendeskripsikan atau menggambarkan data yang telah terkumpul sebagaimana adanya tanpa bermaksud membuat kesimpulan yang berlaku untuk umum atau generalisasi (Sugiyono, 2003). Dalam analisis deskriptif ini dilakukan untuk menggambarkan karakteristik responden dan menggambarkan masing-masing peubah berdasarkan indikatornya masingmasing dengan dilakukan pengkategorian. Adapun perhitungannya menggunakan Program SPSS versi 17.

\section{HASIL DAN PEMBAHASAN}

\section{a. Uji Validitas dan Reliabilitas Instrument}

Berdasarkan hasil perhitungan, semua nilai $r$ hitung untuk setiap item $>0.361$ atau $>$ nilai $r$ tabel (0.361). Oleh karena itu, maka dapat disimpulkan semua item pernyataan indikator semua variabel adalah Valid. Berdasarkan analisis, diperoleh hasil nilai Alpha 0,663. Sedangkan nilai r kritis (uji 2 sisi) dengan signifikansi 0,05 dengan jumlah data $(n)=30$, diperoleh nilai sebesar 0.361 Sementara nilai Corrected Item-Total Correlation seluruh instrumen nilainya di atas angka 0,361 maka dapat disimpulkan bahwa butir-butir instrumen penelitian tersebut Reliabel.

\section{b. Profil Responden}

Karakteristik responden berdasarkan jenis kelamin dapat digambarkan dalam gambar 2, berikut ini.

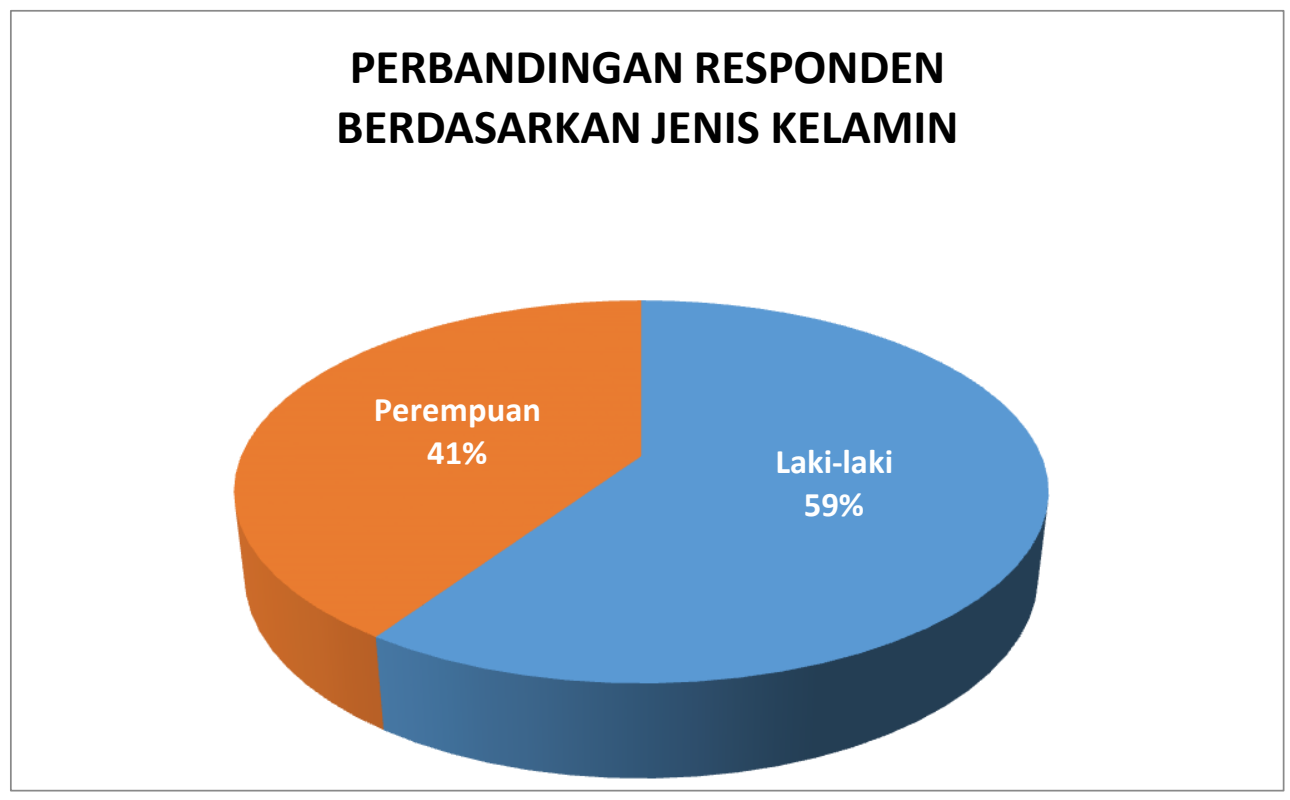

Sumber : Hasil Survei, diolah 2018

Gambar 2. Karakteristik Responden Berdasarkan Jenis Kelamin

Berdasarkan gambar 2, mayoritas responden penganggur adalah laki-laki sebesar 59\%, sedangkan responden perempuan $41 \%$. Dengan demikian, survei ini diharapkan akan memberikan informasi yang mencerminkan bahwa sebagian besar pencari kerja yang tercatat di Disnakertrans di Kabupaten Pandeglang adalah pria.

Berikutnya adalah penjelasan karakteristik responden berdasarkan usia sesuai Tabel 2. 
Tabel 2. Karakteristik Responden Berdasarkan Usia

\begin{tabular}{|c|c|c|c|}
\hline No. & RENTANG USIA & Jumlah & \% \\
\hline 1 & $<=20$ Thn & 94 & 24,42 \\
\hline 2 & $21-30 \mathrm{Thn}$ & 176 & 45,71 \\
\hline 3 & $31-40 \mathrm{Thn}$ & 79 & 20,52 \\
\hline 4 & $>41 \mathrm{Thn}$ & 36 & 9,35 \\
\hline & TOTAL & $\mathbf{3 8 5}$ & $\mathbf{1 0 0}$ \\
\hline
\end{tabular}

Sumber : Hasil Survei, diolah 2018

Berdasarkan karakteristik usia, 45,71\% dari responden merupakan penganggur usia 21-30 tahun. Hal ini dimungkinkan, karena para pencari kerja pada umumnya didominasi oleh remaja usia dewasa sesuai Gambar 3.

\section{PERBANDINGAN JUMLAH RESPONDEN BERDASARKAN RENTANG USIA}

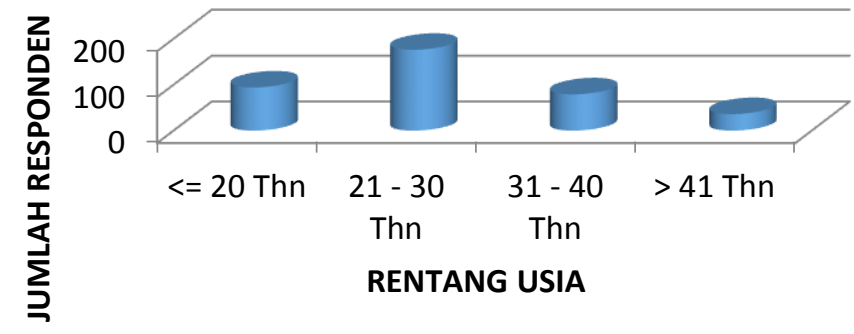

Sumber : Hasil Survei, diolah 2018

Gambar 3. Perbandingan Jumlah Responden Berdasarkan Usia

Adapun karakteristik responden berdasarkan status perkawinan digambarkan pada Gambar 4 berikut:

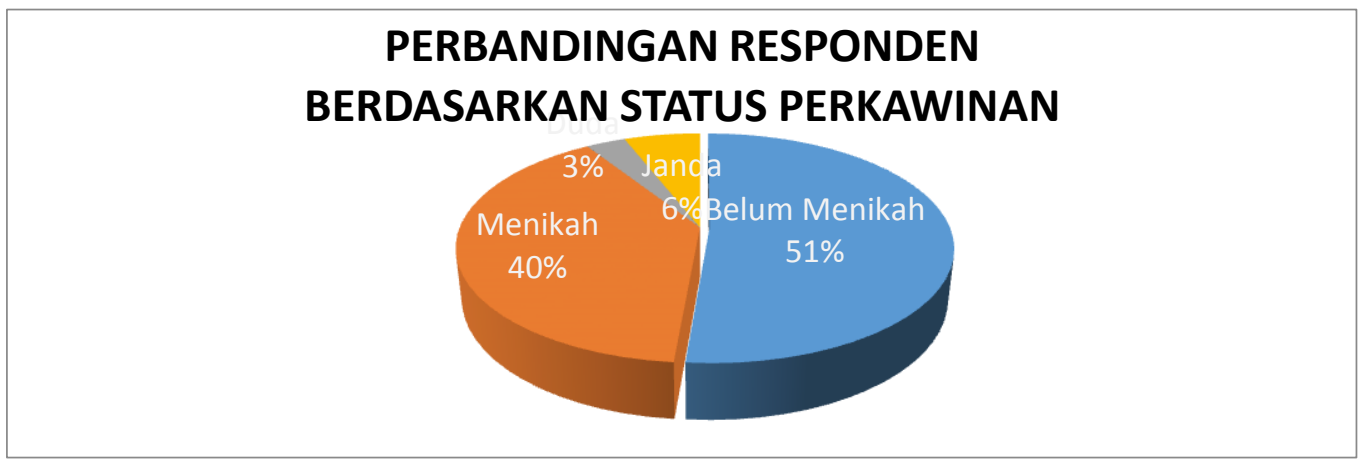

Sumber : Hasil Survei, diolah 2018

Gambar 4. Karakteristik Responden Berdasarkan Status Perkawinan

Berdasarkan status perkawinannya, sesuai dengan data yang ditunjukan di grafik 4.3 responden terbanyak adalah penganggur belum menikah sebesar $51 \%$. Hal ini dapat menjadi cerminan bahwa mayoritas penganggur terjadi pada saat usia perkawinan belum menikah. Namun demikian penganggur dari kalangan responden yang sudah menikahpun terbilang besar, yaitu $40 \%$. Adanya perbedaan yang tidak terlalu signifikan antara responden penganggur dari status perkawinan belum menikah dengan yang sudah menikah, dapat disimpulkan bahwa jumlah penganggur yang terdapat di Kabupaten Pandeglang tidak tergantung pada status perkawinan. Adapun karakteristik responden berdasarkan pendidikannya, yang dijelaskan melalui Gambar 5 berikut: 


\section{PERBANDINGAN RESPONDEN BERDASARKAN PENDIDIKAN}

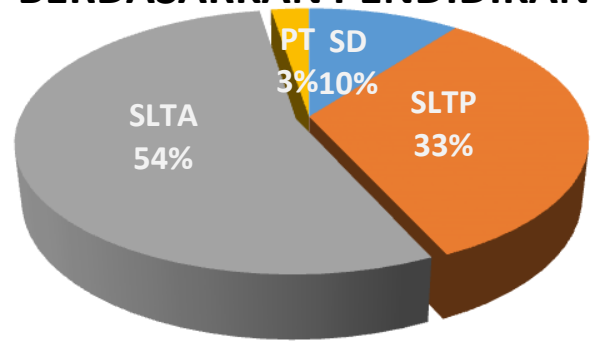

Sumber : Hasil Survei, diolah 2018

Gambar 5 Karakteristik Responden Berdasarkan Pendidikan

Berdasarkan jenjang pendidikan, responden didominasi oleh penganggur dengan tingkat pendidikan menengah, selanjutnya SLTP dan Sekolah Dasar.

\section{c. Analisis Karakteristik Penganggur}

Berdasarkan data yang diperoleh, diketahui bahwa masyarakat yang menganggur sebagian besar sebagian besar pernah berusaha bekerja di sektor informal sebesar $62 \%$, sisanya menyampaikan belum pernah, seperti yang ditunjukan tabel 3 .

Tabel 3. Pencari Kerja yang Pernah di Sektor Informal

\begin{tabular}{|c|l|c|c|}
\hline \multirow{2}{*}{ NO. } & \multicolumn{1}{|c|}{ PERTANYAAN } & \multicolumn{2}{c|}{ PERSENTASI (\%) } \\
\cline { 3 - 4 } & YA & TIDAK \\
\hline 1 & $\begin{array}{l}\text { Jika sampai sekarang Anda belum bekerja, } \\
\text { apakah pernah mencoba berusaha di sektor } \\
\text { informal? }\end{array}$ & $62 \%$ & $38 \%$ \\
\hline
\end{tabular}

Sumber : Hasil Survei, diolah 2018

Setelah diidentifikasi alasan dari 38\% yang belum pernah bekerja di sektor informal, mayoritas disebabkan karena tidak memiliki keahlian dan tidak memiliki modal usaha. Seperti yang tergambar pada tabel 4.

Tabel 4 Alasan Pencari Kerja yang Tidak Berusaha di Sektor Informal

\begin{tabular}{|c|l|c|c|}
\hline No. & Jawaban Responden & Jumlah & Persentase \\
\hline 1 & Tidak Punya Keahlian & 40 & 31,50 \\
\hline 2 & Tidak Punya Modal Usaha & 25 & 19,69 \\
\hline 3 & Kerja Serabutan & 13 & 10,24 \\
\hline 4 & Menunggu Pangilan Kerja & 10 & 7,87 \\
\hline 5 & Menikah / Hamil / Ikut Suami & 15 & 11,81 \\
\hline 6 & Masih Mencari yang lain & 6 & 4,72 \\
\hline 7 & Belum pernah mencoba & 12 & 9,45 \\
\hline 8 & Membantu Orang Tua & 6 & 4,72 \\
\hline & Jumlah & $\mathbf{1 2 7}$ & $\mathbf{1 0 0}$ \\
\hline
\end{tabular}

Sumber : Hasil Survei, diolah 2018 
Selanjutnya, program-program Pemberdayaan Ekonomi Masyarakat dari Pemerintah yang pada umumnya dikenal oleh para pencari kerja adalah Badan Usaha Milik Desa (BUMDes), seperti yang tersaji pada tabel 5 berikut ini:

Tabel 5. Program Pemberdayaan Ekonomi yang dikenal para pencari kerja

\begin{tabular}{|c|l|c|}
\hline No. & PROGRAM PEMERINTAH & \% \\
\hline 1 & Kube & 16 \\
\hline 2 & BumDes & 26 \\
\hline 3 & Program UMKM & 22 \\
\hline 4 & Tidak Mengetahui & 36 \\
\hline & Jumlah & $\mathbf{1 0 0}$ \\
\hline
\end{tabular}

Sumber : Hasil Survei, diolah 2018

\section{d. Analisis Sosioekonomi pendekatan pengangguran}

Berdasarkan hasil survei, ditemukan bahwa faktor-faktor penyebab pengangguran menurut para pencari kerja adalah akibat terbatasnya lapangan pekerjaan. Kemudian faktor penyebab dominan yang kedua adalah karena terbatasnya modal usaha dan malas bekerja. Sedangkan faktor lainnya yang tidak dominan terdistribusi pada alasan lain yang tergambar pada tabel 6 .

Tabel 6 Faktor-faktor Penyebab Pengangguran

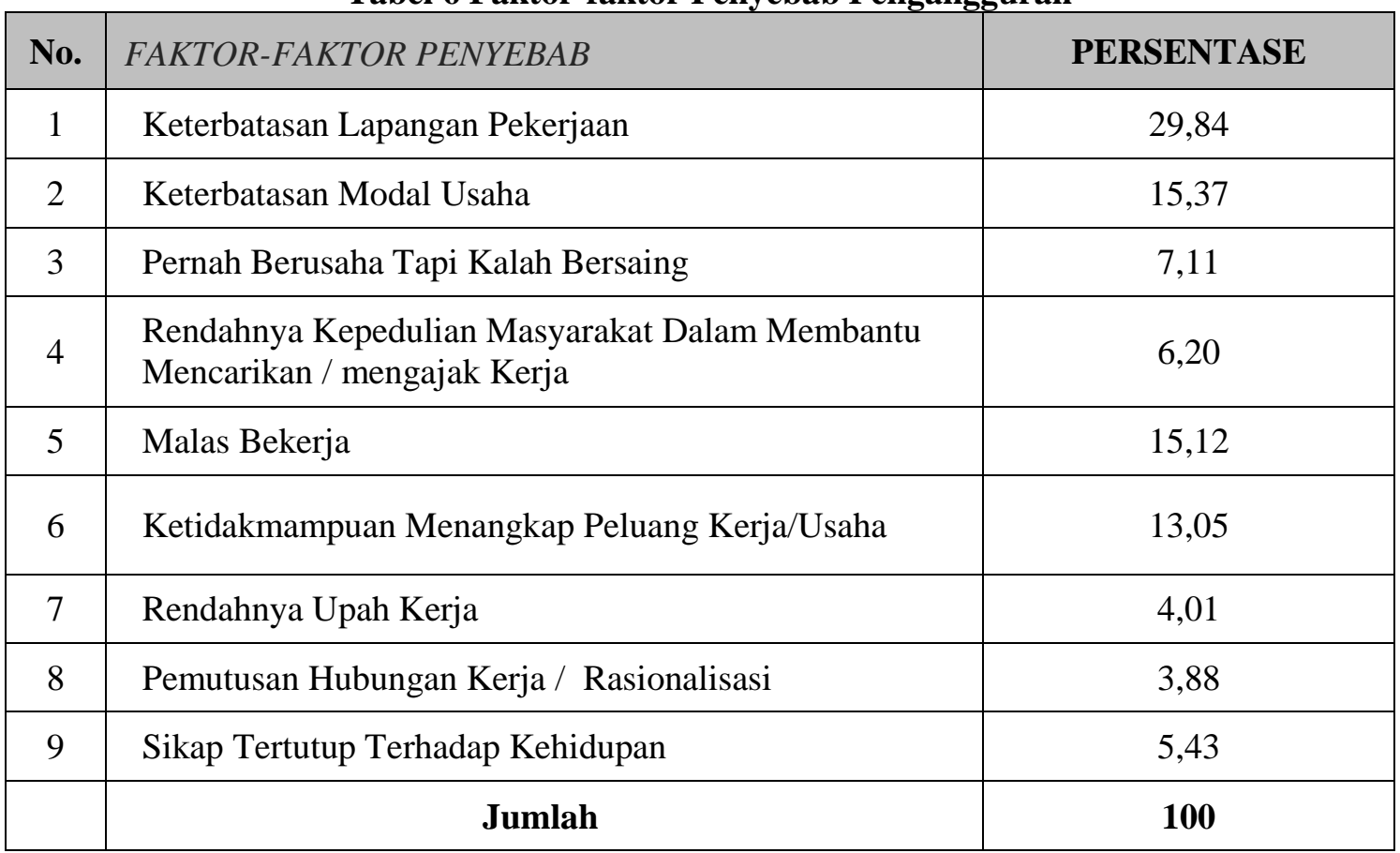

Sumber : Hasil Survei, diolah 2018

\section{KESIMPULAN}

\section{Simpulan}

1. Faktor penyebab pengangguran di Kabupaten Pandeglang disebabkan oleh Keterbatasan Lapangan Pekerjaan, Keterbatasan Modal Usaha, kalah bersaing dalam berusaha; Rendahnya Kepedulian Masyarakat Dalam Membantu Mencarikan (mengajak) Kerja; rendahnya etos kerja; Ketidakmampuan Menangkap Peluang Kerja/Usaha; Rendahnya Upah Kerja; Pemutusan Hubungan Kerja; Sikap Tertutup Terhadap Kehidupan. 
2. faktor penyebab dominan pengangguran adalah pertama karena terbatasnya lapangan pekerjaan. kedua adalah karena terbatasnya modal usaha dan ketiga etos kerja yang rendah (karakter malas).

\section{DAFTAR PUSTAKA}

Alghofari, Farid., 2010, Analisis Tingkat Pengangguran Di Indonesia Tahun 1980-2007. Fakultas Ekonomi Univ Diponegoro. Semarang.

Amir, Amri, 2007, "Pengaruh inflasi dan pertumbuhan ekonomi terhadap pengangguran di Indonesia". Jurnal Inflasi dan Pengangguran Vol. 1 no. 1, 2007, jambi.

Albertus Aditya, 2018, "Pengangguran.” https://id.m.wikipedia.org/wiki/pengangguran, diakses Maret 2018.

Baeti N. 2013. Pengaruh Pengangguran, Pertumbuhan Ekonomi, Dan Pengeluaran Pemerintah Terhadap Pembangunan Manusia Kabupaten/Kota Di Provinsi Jawa Tengah Tahun 2007-2011. Economics Development Analysis Journal (EDAJ),2: (3).

Budiani, NW. Efektivitas Program Penanggulangan Pengangguran Karang Taruna Eka Taruna Bhakti Desa Sumerta Kelod Kecamatan Denpasar Timur Kota Denpasar. Jurnal Ekonomi dan Sosial, I N P U T. Vol. 2 (1):49-57.

Firdhania R, Muslihatinningsih F. 2017. Faktor-Faktor yang Mempengaruhi Tingkat Pengangguran di Kabupaten Jember. e-Journal Ekonomi Bisnis dan Akuntansi,Vol. IV (1) : 117-121.

Glendoh. 2001. Pembinaan dan Pengembangan Usaha Kecil. Jurnal Manajemen \& Kewirausahaan Vol. 3 (1): 1 - 13.https://www.academia.edu/8949772/Kewirausahaan_di_Indonesia. Diakses 28 Mei 2015.

Ikhsan M. 2004. Mengembalikan laju pertumbuhan ekonomi dalam jangka menengah: peran usaha kecil dan menengah. Jurnal analisis sosial.

Kurnia D. 2016. Pengangguran di Indonesia: Dalam Persaingan dan Kesadaran Usaha. https://www.academia.edu/. diakses 12 April 2018.

Kuncoro, Mudrajad. Ekonomi Pembangunan, edisi ketiga. Yogyakarta: Penerbit UPP AMP Y KPN. 2003.

Kaufman, BE and Hotchkiss, JL. 1999. The Economic Labor Markets. USA: Georgia State University.

Kaufman, B.E. dan Hotckiss, J.L. 1999. The Economics of Labor Markets. Fifth Edition. USA: The Dryden Press.

Kistina, A. 2012. Standarisasi Kompetensi sebagai upaya perlindungan TKI. Diakses dari portal www.garuda. Org pada 16 November 2018.

Safina L dan Rahayu SE. 2011. Analisis Pengaruh Investasi Pemerintah Dan Swasta Terhadap Penciptaan Kesempatan Kerja Di Sumatera Utara. Jurnal Manajemen \& Bisnis Vol.11(1).

Mankiw, N. Gregory. 2006. Makroekonomi. Edisi Keenam. Terjemahan Haris Munandar. Jakarta: Erlangga.

Mulyadi M. 2016. Peran Pemerintah Dalam Mengatasi Pengangguran Dan Kemiskinan Dalam Masyarakat. Kajian Vol. 21 No. 3: $221-236$

Nadilla U dan Farlian T. 2018. Pengaruh PDRB Perkapita, Pendidikan, Pengangguran, Dan Jumlah Polisi Terhadap Angka Kriminalitas Di Provinsi Aceh. Jurnal Ilmiah Mahasiswa (JIM) Ekonomi Pembangunan Fakultas Ekonomi dan Bisnis Unsyiah Vol.3 (1): 110-118.

Nanga M. 2001. Makro Ekonomi Teori, Masalah, dan Kebijakan. Jakarta: Rajawali Pers.

Octaviani, Dian. 2001. Inflasi, Pengangguran, dan Kemiskinan di Indonesia: Analisis Indeks Forrester Greer \& Horbecke. Media Ekonomi, Vol. 7 (8): 100- 118

Putong I. 2003. Ekonomi Mikro \& Makro, edisi kedua. Jakarta: Penerbit Ghalia Indonesia.

Poyoh A, Kapantow GHM, Mandei JR. 2017. Faktor-Faktor Yang Mempengaruhi Tingkat Penggangguran Di Provinsi Sulawesi Utara. Agri-SosioEkonomiUnsrat, Vol. 13 No. 1A,: 55 - 66.

Prasaja MH. 2013. Pengaruh Investasi Asing, Jumlah Penduduk Dan Inflasi Terhadap Pengangguran Terdidik Di Jawa Tengah Periode Tahun 1980-2011. Jurusan Ekonomi Pembangunan, Fakultas Ekonomi, Universitas Negeri Semarang, Indonesia Vol. 3 (2): 72-84. 
Samuelson. 1997. Makro Ekonomi, Diterjemahkan oleh Haris A, Munandar, Fredy Saragih, dan Rudi Tambunan. Jakarta: Penerbit Erlangga.

Samuelson, A. P. dan Nordhaus, D. W. 2004. Mikroekonomi. Jakarta: Erlangga.

Segal, G., \& Borgia, D., Schoenfeld, J. 2005. The Motivation to Become an Entreprenur. International Journal of Entrepreneurial Behavior \& Research,11: 42-57.

Sinamo, Jansen. 2005. Delapan Etos Kerja Profesional: Navigator Anda Menuju Sukses. Grafika Mardi Yuana, Bogor.

Subagyo, Sukirno, Sadono. 2000. Makroekonomi Teori Pengantar. Jakarta: PT. RajaGrafindo Persada.

Sugiyono. 2016. Metode Penelitian Kuantitatif Kualitatif dan R \& D, Bandung: Alfabeta.

Sukirno S, 2010. Makroekonomi Teori Pengantar. Edisi Ketiga, Jakarta: Raja Grafindo Persada

Sumarsono S. 2009. Teori dan Kebijakan Publik Ekonomi Sumber Daya Manusia. Yogyakarta: Graha Ilmu.

Swaramarinda, Darma Rika. 2014. Analisis Dampak Pengangguran terhadap kemiskinan di DKI Jakarta. Jurnal Pendidikan Ekonomi dan Bisnis (JPEB) Vol. 2 No. 2: 63-70.

Todaro, Michael P. dan Smith, Stephen C. 2004. Pembangunan Ekonomi di Dunia Ketiga. Edisi Kedelapan, Jilid 1, Terjemahan Haris Munandar, Jakarta: Erlangga

Wijaya, Tony. 2007. Hubungan Adversity Intelligence dengan Intensi Berwirausaha (Sudi Empiris pada Siswa SMKN 7 Yogyakarta). Jurnal Manajemen dan Kewirausahaan Vol 9: 117-127

Yacoub, Yarlina. 2012. Pengaruh Tingkat Pengangguran terhadap Tingkat Kemiskinan Kabupaten/Kota di Provinsi Kalimantan Barat. Jurnal EKSOS. Volume 8 (3): 176 - 185.

Zhao, H., Seibert, S.E., \& Hills, G.E. 2005. The Mediating Role of Self Efficacy in the Development of Entrepreneurial Intention. Journal of Applied Psychology,90: 1265-1271

Zulhanafi, Hasdi Aimon, Efrizal Syofyan. Analisis Faktor-Faktor Yang Mempengaruhi Produktivitas Dan Tingkat Pengangguran Di Indonesia. Jurnal Kajian Ekonomi, Vol. II: 03. 